\title{
The Value of Psychological Resources in Actualization of the Sense Construct
}

\section{Значення психологічних ресурсів в актуалізації смислових конструктів}

\author{
Olena Shtepa \\ Олена Штепа \\ Ph.D. in Psychology, \\ Assistant Professor \\ кандидат психологічних наук, \\ доцент \\ E-mail: Olena.Shtepa@lnu.edu.ua \\ orcid.org/0000-0002-5396-3279 \\ Researcher ID: S-9557-2018

\section{Ivan Franko National University of Lviv, Lviv, Ukraine} \\ 1, Universytetska Str., \\ Lviv, 79000 \\ Львівський національний \\ університет ілені Івана \\ Франка, л. Львів, Україна \\ вул. Університетська, 1, \\ м. Львів, 79000 \\ Original manuscript received April 21, 2019 \\ Revised manuscript accepted May 16, 2019
}

\section{ABSTRACT}

The problem of empirical verification of the bilateral updating of sense constructs is formulated. Empirical research was implemented in the Nelson model, which allowed determining the nature of the problem in the present situation. The available condition is socio-cultural context of life, so it is stated that the study was conducted from October 2018 to April 2019. In the present situation, the study of the sense construct is actualized by the resources of responsibility, belief in good, love, help to others and the inactivity of the motives of avoidance and competition.

The main indicators of the resource actualization of the sense construct are the competitive motive, the motive of self-esteem, the motive of volitional 
effort, the resource of helping others and the resource of success, the value of stimulation, the lack of value of power and the non-determination of the new sense construct by the content from the previous one, which indicates the presence of semantic dispositions. The main indicators of the motivational actualization of the sense construct are the motives of avoidance and competitiveness, the values of tradition and universalism, the overall level of life-sense orientations, locus-control Me, the overall level of life-sense orientations is an indicator in the semantic construct, which indicates the presence of prejudice, motive. The results of the study were proved that the resource way of actualization the sense construct was possible with the ability of the individual to operate with his own psychological resources, which could be made more expressive through the motives of knowledge and evaluation of potential. The purpose of psychological resources in the actualization of the sense construct is to maintain communication with the metanarrative and, in fact, the approach of the personality in the process of sense's transformations to authenticity.

Key words: psychological resources, sense construct, actualization, motivational values, motives, ethical position, resource and motivation-oriented way of actualization.

\section{Вступ}

Теоретична інтерпретація психологічних ресурсів особистості як екзистенціально-когнітивних стратегій інтерпретації людиною значущості події (Штепа, 2019: 92) зумовила необхідність верифікації цього означення. Можливість перевірки ми вбачаємо шляхом аналізу ролі психологічних ресурсів в актуалізації смислових конструктів. Смислові конструкти визначено Д. Леонтьєвим як «стійку категоріальну шкалу, що представлена у психіці суб'єкта на рівні глибинних структур образу світу, що виявляє значущість для людини певної характеристики об’єктів і явищ дійсності та виконує функцію диференціації й оцінки об'єктів і явищ за цим параметром, наслідком чого є приписування їм відповідного життєвого смислу» (Леонтьєв, 2003: 217). Дослідником простежено два способи актуалізації смислових конструктів - через механізм мотиваційної установки і через механізм смислової диспозиції (Леонтьєв, 2003: 222). На основі тези С. Максименка 
про те, що смисли утворюються внаслідок «установлення внутрішнього зв'язку особистих переживань із цінністю» (Максименко, 2016: 15), ми припустили, що психологічні ресурси можуть бути виявом такого переживання як проживання значущості життя.

Актуалізацію пов'язують із мотивацією i досвідом особистості (Krems \& Kenrick, 2017). У інтерпретуванні Дж. Бауера і Д. МакАдамса (Bauer et al., 2011: 124), актуалізація є вибором людини щодо власного особистісного зростання. Відтак, актуалізація може бути зумовлена соціокультурним контекстом, що концептуалізований у цінностях, а також контентом особистості, кристалізованим у досвіді, оскільки у життєвій ситуації особистість одночасно означує ситуацію і самовизначається (Знаков, 2010: 108). На погляд В. Знакова (2005), саморозуміння дає людині змогу звернутися до власних джерел. Таким джерелом може бути як метанаратив - універсальне, «велике оповідування» щодо трансцендентних, «передустановлених» заповідей, який трактує буттєвий смисл світу і буття особистості у ньому, до якого сучасна особистість втратила довіру (Извеков, 2012: 94), так і соціокультурний дискурс, насичений привабливими і часто дієвими «інтерпретаційними схемами» (Розуміння та інтерпретація життєвого досвіду, 2013: 15). На основі ідеї А. Петровського й М. Ярошевського (1998) щодо базисних і метапонять у психології, зокрема відповідного співвідношення мотивації і цінностей, ми припустили, що психологічні ресурси можуть бути базисними відносно феномену саморозуміння. Оскільки (само)розуміння тлумачать як занурення до контексту (Брудный, 2005: 248), то логічно припустити, що етичні позиції (Forsyth et al., 2008: 176), що формуються як на основі соціалізації, так і особистого життєвого досвіду прийняття етичних рішень, можна вважати виявом саморозуміння особи.

Теоретично ми дійшли висновку, що джерелами актуалізації смислового конструкту є метанаратив і соціокуль- 
турний контекст, що у психологічній реальності особистості можуть бути виражені змістовно через метапоняття саморозуміння і цінностей, а функціонально - через базисні поняття психологічної ресурсності й мотивації. Подальшу емпіричну верифікацію двобічної актуалізації смислових конструктів було сформульовано за мету дослідження.

\section{Завдання статті}

1. Емпірично з'ясувати особливості ресурсної та мотиваційної актуалізації смислових конструктів.

2. Проінтерпретувати значення психологічних ресурсів в актуалізації смислових конструктів.

\section{Методи та методики дослідження}

Емпіричне дослідження було реалізовано у моделі Нельсона, що полягає у визначенні сутності проблеми за наявних умов. Наявними умовами є соціально-культурний контекст життя, тому варто вказати, що термінальними межами дослідження є жовтень 2018 - квітень 2019 рр. За аксіоматичне положення дослідження було прийнято те, що інтенція, яка формується внаслідок актуалізації смислового конструкту, є виявом психологічної реальності особистості (Капустін, 2017: 70).

Емпіричним дескриптором смислового конструкту ми допустили загальний рівень смисложиттєвих орієнтацій, оскільки він дає змогу охарактеризувати саме ступінь і насиченість життя змістами. Емпіричними дескрипторами актуалізації смислових конструктів через категоріальну установку ми припустили цінності, оскільки саме цінності можна вважати соціокультурними «інтерпретаційними схемами». Смислові диспозиції ми припустили за можливе емпірично означити за допомогою психологічних ресурсів, оскільки і диспозиції, і ресурси формуються внаслідок життєвого досвіду і є індикаторами значущості певної події. Емпіричні гіпотези дослідження: а) чинниками загального рівня смисложиттєвих орієнтацій є мотиви і психоло- 
гічні ресурси; б) існує зв'язок між загальним рівнем смисложиттєвих орієнтацій, цінностей, етичною позицією, мотивами, психологічними ресурсами; в) головні компоненти психологічної реальності особистості різняться за їі ціннісної та ресурсної зумовленості.

У емпіричному дослідженні взяли участь 214 осіб(із них $63 \%$ жінки і $37 \%$ чоловіки) віком 20-65 років ( $\mathrm{M}=33,59$; $\mathrm{SD}=6,6$ ) (студенти університету 4-6-го курсів гуманітарних і природничих спеціальностей, учителі, асистенти вчителів у інклюзивних класах, викладачі коледжів, спортивні тренери, приватні підприємці, менеджери, офісні працівники, правники, психологи, лікарі, домогосподарки, пенсіонери). До психодіагностичного інструментарію було включено опитувальник мотиваційних цінностей (адаптація I. Семків методики PVQ Ш. Шварца) (Семків, 2013: 25), опитувальник діагностики компонентів мотиваційної структури В. Гербачевського (Батаршев, 2006: 149), опитувальник смисложиттєвих орієнтацій (адаптація Д. Лєонтьєвим методики «Цілі у житті» Дж. Крамбо та Л. Махоліка) (Слотина, 2008: 252), опитувальник етичних позицій (адаптація А. Фьодоровим, І. Бадієвим опитувальника Ethics Position Questionnaire (EPQ) Д. Форсайта) (Forsyth et al., 2008: 178), опитувальник психологічної ресурсності особистості (О. Штепа, 2018: 393).

\section{Результати та дискусії}

Із метою характеристики емпіричної структури контексту актуалізації смислового конструкту було здійснено багатофакторний аналіз, до якого було включено шкали загального рівня смисложиттєвих орієнтацій, етичних позицій, мотиваційних цінностей, мотивів, психологічної ресурсності. У результаті факторизації даних за Principal components (факторна вага $>0,7$ ) було встановлено, що наявна емпірична модель містить 12 факторів, які у сукупності пояснюють $67,7 \%$ дисперсії. Іерархічний багатофакторний аналіз виявив, що мотиваційні цінності гедонізму 
$(-0,67)$ і досягнення $(0,69)$, а також мотив уникання $(-0,75)$ є чинниками загального рівня психологічної ресурсності. Виявлене, на наш погляд, збігається з твердженням щодо функціонального вияву саморегуляції у перетворенні нейтрального змісту на смисл за смислового зв’язування особистих переживань із цінністю (Максименко, 2016: 15).

За допомогою покрокового регресійного аналізу було встановлено, що чинниками загального рівня смисложиттєвих орієнтацій є ресурс допомоги іншим і мотиваційна цінність влади (p < 0,01) (табл. 1).

Таблиия 1

Результати покрокового регресійного аналізу для шкали «загальний рівень смисложиттєвих орієнтацій»

\begin{tabular}{|c|c|c|c|c|c|c|c|}
\hline \multirow[t]{2}{*}{$\frac{a}{v_{0}^{2}}$} & \multirow[t]{2}{*}{ Intercept } & \multirow[t]{2}{*}{ Beta } & \multirow{2}{*}{$\begin{array}{l}\text { Std. } \\
\text { Err. } \\
\text { - of } \\
\text { Beta }\end{array}$} & B & \begin{tabular}{|c} 
Std. \\
Err. - \\
of B \\
\end{tabular} & $t(210)$ & p-level \\
\hline & & & & 91,39 & 10,12 & 9,03 & 0,000000 \\
\hline 1 & $\begin{array}{l}\text { Ресурс допомоги } \\
\text { іншим }\end{array}$ & 0,39 & 0,07 & 6,61 & 1,09 & 6,06 & 0,000000 \\
\hline 2 & $\begin{array}{l}\text { Мотиваційна } \\
\text { цінність влади }\end{array}$ & 0,20 & 0,08 & 4,22 & 1,59 & 2,65 & 0,008670 \\
\hline
\end{tabular}

Результати регресійного аналізу підтвердили, що доцільно характеризувати два шляхи актуалізації смислового конструкту - ресурсний і мотиваційний, причому ресурсний передує мотиваційному.

Результати процесуального аналізу методом CausaAnd-Effect (рис. 1) дали змогу з'ясувати, що ресурс допомоги іншим із високою ймовірністю зумовлює змістовну насиченість процесу життя - одного з двох головних факторів онтологічної значущості життя, тобто життя цікавого і сповненого смислом.

Мотиваційна цінність прагнення влади значною мірою може зумовлювати відчуття особи себе володарем власного життя, здатності контролювати події власного життя. 
Cause-And-Effect Diagram

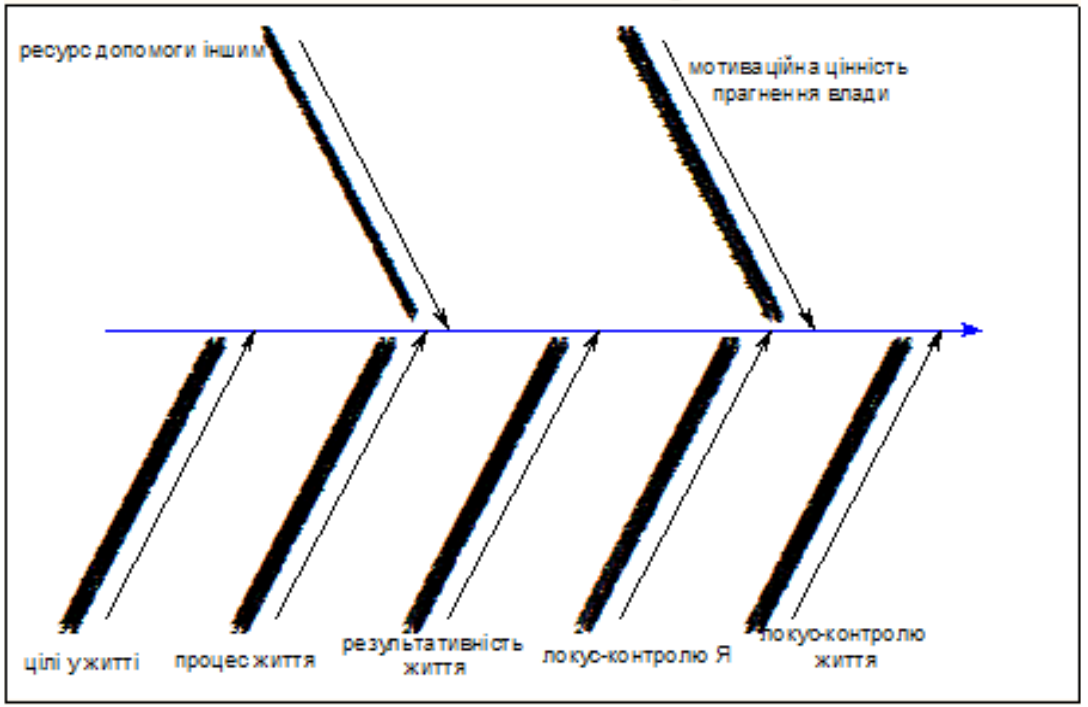

Puc. 1. Результати процесуального аналізу показників смисложиттєвих орієнтацій як ефектів одночасної дії психологічного ресурсу допомоги іншим і цінності влади

Із метою конкретизації емпіричної структури контексту актуалізації смислового конструкту в наявних умовах було здійснено дві ітерації їі 12-факторної моделі та методом Principal components (факторна вага $>0,7$ ) отримано 6-факторну емпіричну модель, яка у сукупності пояснювала $73,13 \%$ дисперсії (табл. 2).

Результати багатофакторного аналізу продемонстрували, що контент актуалізованого смислового конструкту в наявних умовах дійсно містить мотиви, психологічні ресурси, цінності, етичну позицію як вияв саморозуміння. Підтвердженням того, що означено саме смисловий конструкт, є те, що усі показники смисложиттєвих орієнтацій увійшли до фактора 1 (пояснює 30,5\% дисперсії). Важливо звернути увагу на те, що фактор 2 (13,9\%) представлено показниками уміння людини оперувати власними ресур- 
сами. Емпірична модель демонструє важливість для смислоутворення усвідомленості цінностей досягнення і влади (фактор $3(9,3 \%$ )) і відсутність мотивів уникання й змагальності (фактор 4 (7,6\%)). Фактор 5 (6,4\%) містить психологічні ресурси, що є визначальними для характеристики їі змісту і рівня. Показники етичної позиції, що є виявом саморозуміння особистості, увійшли до фактора 6 (5,4\%).

Таблиия 2

Результати багатофакторного аналізу структури контексту актуалізації смислового конструкту за наявних умов

\begin{tabular}{|l|c|c|c|c|c|c|}
\hline \multirow{2}{*}{\multicolumn{1}{|c|}{ Шкали }} & \multicolumn{6}{|c|}{ Фактори } \\
\cline { 2 - 7 } & $\mathbf{1}$ & $\mathbf{2}$ & $\mathbf{3}$ & $\mathbf{4}$ & $\mathbf{5}$ & $\mathbf{6}$ \\
\hline Ресурс допомоги іншим & 0,28 & 0,23 & $-0,11$ & $-0,03$ & $\mathbf{0 , 6 7}$ & 0,15 \\
\hline Ресурс любові & $\mathbf{0 , 1 4}$ & 0,16 & 0,05 & 0,00 & $\mathbf{0 , 8 1}$ & 0,01 \\
\hline Ресурс віри у добро & 0,19 & 0,32 & $-0,09$ & 0,03 & $\mathbf{0 , 6 7}$ & $-0,16$ \\
\hline Ресурс відповідальності & 0,17 & 0,05 & 0,01 & $-0,02$ & $\mathbf{0 , 8 4}$ & 0,06 \\
\hline Знання власних ресурсів & 0,11 & $\mathbf{0 , 9 0}$ & 0,10 & 0,02 & 0,17 & 0,05 \\
\hline Уміння оновлювати ресурси & 0,11 & $\mathbf{0 , 9 2}$ & 0,10 & 0,02 & 0,13 & $-0,01$ \\
\hline Уміння вміщувати ресурси & $\mathbf{0 , 1 7}$ & $\mathbf{0 , 9 0}$ & 0,02 & 0,06 & 0,19 & 0,01 \\
\hline $\begin{array}{l}\text { Мотиваційна цінність } \\
\text { досягнення }\end{array}$ & $-0,08$ & 0,12 & $\mathbf{0 , 8 5}$ & 0,03 & 0,10 & 0,03 \\
\hline Мотиваційна цінність влади & 0,05 & 0,03 & $\mathbf{0 , 8 6}$ & 0,03 & $-0,15$ & 0,01 \\
\hline Мотив уникання & $-0,06$ & 0,04 & 0,06 & $-\mathbf{0 , 8 8}$ & $-0,01$ & 0,14 \\
\hline Мотив змагальний & $-0,10$ & $-0,11$ & $-0,13$ & $-\mathbf{0 , 8 7}$ & 0,02 & $-0,07$ \\
\hline Цілі у житті (СжО) & $\mathbf{0 , 7 4}$ & 0,16 & $-0,04$ & $-0,04$ & 0,17 & 0,08 \\
\hline Процес життя (СЖО) & $\mathbf{0 , 8 4}$ & 0,04 & 0,02 & 0,05 & 0,17 & 0,01 \\
\hline Результативність життя (СЖО) & $\mathbf{0 , 8 7}$ & 0,12 & $-0,01$ & 0,05 & 0,13 & 0,04 \\
\hline Локус-контролю Я (СЖО) & $\mathbf{0 , 8 4}$ & 0,18 & 0,02 & 0,04 & 0,16 & 0,05 \\
\hline Локус-контролю життя (СЖО) & $\mathbf{0 , 8 0}$ & $-0,00$ & $-0,05$ & 0,11 & 0,08 & $-0,10$ \\
\hline $\begin{array}{l}\text { Загальний рівень смисло- } \\
\text { життєвих орієнтацій (СЖО) }\end{array}$ & $\mathbf{0 , 9 3}$ & 0,08 & 0,02 & 0,05 & 0,14 & 0,02 \\
\hline Ідеалізм & 0,06 & 0,42 & $-0,00$ & $-0,04$ & 0,24 & $\mathbf{0 , 6 6}$ \\
\hline Релятивізм & 0,02 & $-0,05$ & 0,04 & $-0,05$ & $-0,03$ & $\mathbf{0 , 9 0}$ \\
\hline
\end{tabular}


Із метою встановлення і характеристики зв'язків між компонентами контенту актуалізації смислового конструкту було здійснено кореляційний аналіз, головні результати якого ілюструє рис. 2. Коливання абсолютної величини коефіцієнтів інтеркореляцій між компонентами контенту актуалізації смислового конструкту і загальним рівнем смисложиттєвих орієнтацій знаходяться у діапазоні $0,23-0,54$.

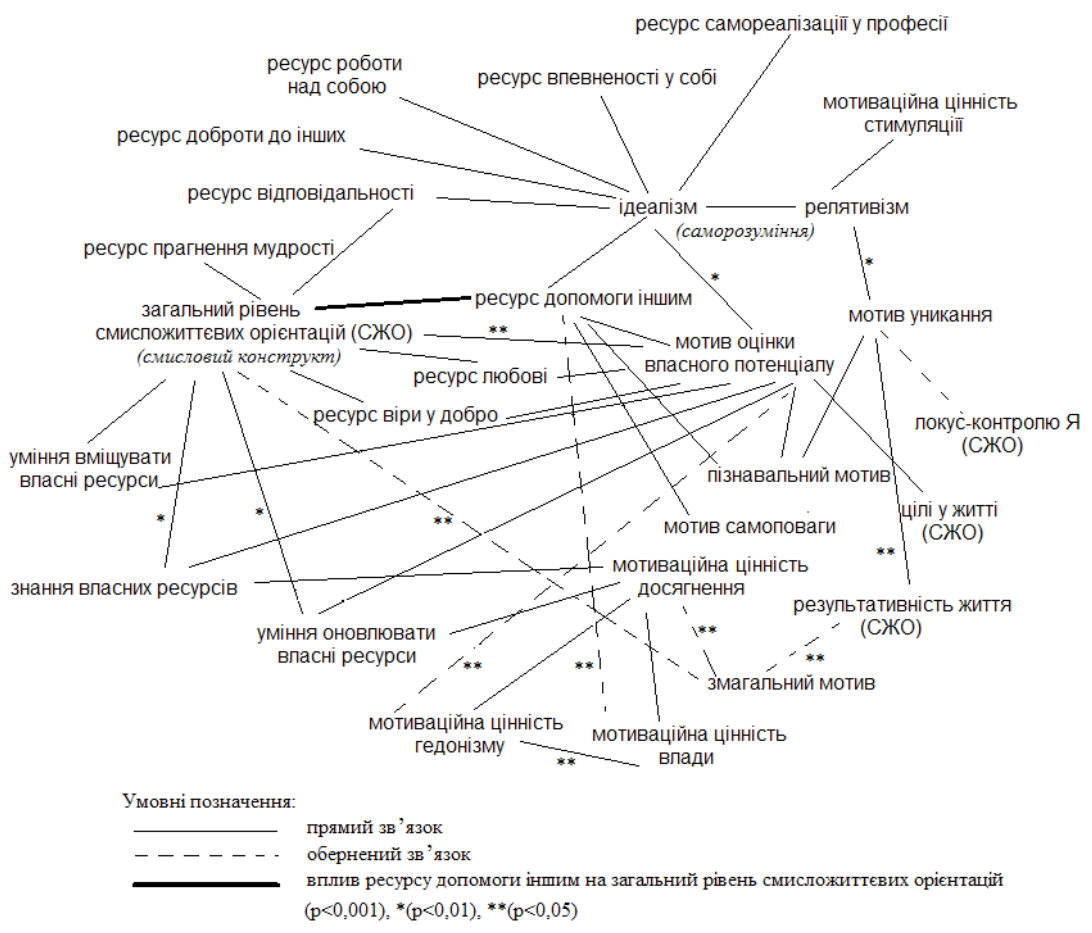

Puc. 2. Кореляційний граф характеру зв'язків між компонентами контенту актуалізації смислового конструкту

Вважаємо за доцільне в аналізі зв'язків між компонентами контенту актуалізації смислового конструкту звернути увагу на те, що на статистично значущому рівні загальний рівень смисложиттєвих орієнтацій безпосередньо 
пов' язаний із двома мотивами - мотивом оцінки власного потенціалу і змагальним мотивом, а також п'ятьма психологічними ресурсами й усіма показниками уміння людини оперувати власними ресурсами. Етична позиція як емпіричний вияв саморозуміння через показники «ідеалізму - релятивізму» пов'язана із загальним рівнем смисложиттєвих орієнтацій через психологічні ресурси допомоги іншим і відповідальності, а також мотив оцінки власного потенціалу. Мотиваційна цінність досягнення пов' язана із загальним рівнем смисложиттєвих орієнтацій через змагальний мотив і знання власних ресурсів, мотиваційна цінність гедонізму - через мотив оцінки власного потенціалу, мотиваційна цінність влади - через ресурс допомоги іншим. Оскільки ресурс допомоги іншим пов' язаний з обома джерелами смислового конструкту - саморозумінням i цінностями, то цей ресурс можна означити як смислоперетворювальний. Перетворення смислу, як демонструють результати кореляційного налізу, відбувається у три способи, зокрема, через мотиви пізнання, самоповаги, оцінки власного потенціалу. Саме у зв'язках із певними мотивами конкретизується зміст онтологічної насиченості життя, а саме: змагальний мотив і мотив уникання увиразнюють результативність життя, мотив уникання - локус-контролю життя, мотив оцінки власного потенціалу - цілі у житті. Саме через мотив оцінки власного потенціалу усвідомлюється оперування людиною власними психологічними ресурсами. Змагальний мотив, вочевидь, є неконструктивним для відчуття людиною результативності власного життя і переживання досягнення.

Із метою з'ясувати, чи різняться головні компоненти психологічної реальності особистості за їі ціннісної та ресурсної зумовленості, було застосовано метод Principal Components, за якого активними показниками були почергово «ресурсність» (за показником загального рівня психологічної ресурсності) та «мотиваційність» (визначено нами за показником математичної суми балів усіх діагностова- 
них у досліджуваного мотивів; далі, на кшталт емоційності, чим більша сума балів, тим вищим є вияв «мотиваційності»). За кожного з визначених активних показників аналізу було надано усі компоненти контенту актуалізації смислового конструкту (табл. 3,4$).$ У табл. 3 унаочнено зміст перших 8-ми факторів, що у сукупності пояснюють $82,6 \%$ контенту. За результатами аналізу головних компонентів установлено, що дані, включені до аналізу, структуровані за 20-ма факторами, що характеризує емпіричну модель актуалізації смислового конструкту за активації його контенту ресурсністю як значно розгалужену.

таблиия 3

Результати аналізу головних компонентів психологічної реальності особистості за її ресурсної зумовленості

\begin{tabular}{|c|c|c|c|c|c|c|c|c|}
\hline \multirow{2}{*}{ Шкали } & \multicolumn{8}{|c|}{ Об’єднання шкал у фактори } \\
\hline & 1 & 2 & \begin{tabular}{|l|}
3 \\
\end{tabular} & \begin{tabular}{|l|} 
\\
\end{tabular} & 5 & 6 & 7 & 8 \\
\hline 1 & 2 & 3 & 4 & 5 & & & 8 & 9 \\
\hline Ресурс упевненості у собі & $-0,12$ & 0,01 & $-0,13$ & $-0,40$ & $-0,50$ & $-0,21$ & 0,08 & 0,32 \\
\hline Ресурс доброти до інших & 0,09 & 0,55 & 0,10 & 0,24 & 0,57 & $-0,14$ & $-0,21$ & 0,17 \\
\hline Ресурс допомоги & $-0,16$ & 0,74 & 0,20 & 0,36 & 0,04 & 0,04 & 0,21 & $-0,12$ \\
\hline Ресурс успіху & 0,04 & 0,61 & 0,39 & $-0,12$ & $-0,38$ & 0,13 & $-0,13$ & $-0,12$ \\
\hline Pecy & $-0,03$ & 0,13 & $-0,14$ & 0,16 & $-0,35$ & $5-0,10$ & $-0,19$ & 0,72 \\
\hline & 0,35 & 0,06 & & & $-0,28$ & 0,58 & 0,08 & \\
\hline Pecy & 0,01 & 0,46 & 0,16 & 0,38 & 0,33 & $-0,16$ & $-0,21$ & $-0,39$ \\
\hline $\begin{array}{l}\text { Рес } \\
\text { муд }\end{array}$ & 0,27 & 0,18 & 0,40 & 0,41 & $-0,34$ & $4-0,1$ & $-0,12$ & 0,21 \\
\hline Pecs & $-0,00$ & $-0,08$ & 0,43 & 0,08 & 0,60 & $-0,08$ & 0,15 & $-0,00$ \\
\hline $\begin{array}{l}\text { Pecy } \\
\text { חpod }\end{array}$ & 0,29 & $-0,48$ & 0,51 & $-0,11$ & $-0,22$ & 20,21 & 0,28 & 0,13 \\
\hline Ресурс відповідальності & 0,02 & 0,24 & 0,02 & 0,60 & 0,02 & $-0,27$ & $7-0,06$ & 0,30 \\
\hline Знання власних ресурсів & $-0,45$ & 0,00 & $-0,16$ & $-0,62$ & $-0,00$ & 0,27 & $-0,27$ & $-0,01$ \\
\hline $\begin{array}{l}\text { Уміння оновлювати } \\
\text { ресурси }\end{array}$ & $-0,52$ & 0,13 & $-0,23$ & $-0,14$ & 0,46 & 0,43 & $-0,25 \mid$ & 0,12 \\
\hline $\begin{array}{l}\text { Уміння вміщувати } \\
\text { ресурси }\end{array}$ & $-0,57$ & 0,09 & $-0,24$ & $-0,28$ & 0,37 & 0,10 & $-0,33$ & 0,10 \\
\hline Цінність конформізму & 0,56 & $-0,40$ & $-0,38$ & $-0,12$ & 0,01 & $-0,07$ & $7-0,0$ & $-0,1$ \\
\hline
\end{tabular}


Продовження табл. 3

\begin{tabular}{|c|c|c|c|c|c|c|c|c|}
\hline 1 & 2 & 3 & 4 & 5 & 6 & 7 & 8 & 9 \\
\hline Цінність традиції & 0,22 & $-0,22$ & $-0,64$ & 0,30 & $-0,09$ & $-0,21$ & 0,34 & $-0,03$ \\
\hline $\begin{array}{l}\text { Цінність } \\
\text { доброзичливості }\end{array}$ & 0,35 & $-0,25 \mid$ & $-0,46$ & 0,07 & 0,55 & 0,18 & $-0,06$ & 0,06 \\
\hline Цінність універсалізму & 0,25 & $-0,19$ & $-0,14$ & 0,47 & $-0,12$ & $-0,05$ & $-0,59$ & 0,24 \\
\hline Цінність самостійності & 0,31 & $-0,16$ & 0,00 & 0,33 & $-0,49$ & 0,46 & $-0,15$ & $-0,28$ \\
\hline Цінність стимуляції & 0,41 & 0,62 & $-0,43$ & $-0,07$ & $-0,01$ & $-0,07$ & $-0,04$ & $-0,07$ \\
\hline Цінність гедонізму & 0,29 & 0,36 & $-0,56$ & 0,09 & 0,12 & 0,33 & 0,00 & $-0,16$ \\
\hline Цінність досягне & $-0,02$ & 0,54 & $-0,40$ & $-0,19$ & $-0,45$ & $-0,00$ & $-0,01$ & $-0,27$ \\
\hline ть влади & $-0,34$ & 0,11 & $-0,70$ & $-0,12$ & $-0,42$ & $-0,08$ & $-0,09$ & 0,01 \\
\hline езпеки & 0,09 & $-0,38$ & $-0,17$ & $-0,23$ & 0,15 & $-0,32$ & $-0,57$ & $-0,30$ \\
\hline $\begin{array}{l}\text { середженості } \\
\text { i }\end{array}$ & 0,06 & 0,48 & $-0,61$ & 0,02 & $-0,19$ & 0,28 & $-0,09$ & 0,05 \\
\hline ьний мотив & 0,15 & 0,52 & $-0,32$ & $-0,10$ & 0,21 & 0,05 & 0,53 & $-0,09$ \\
\hline Мотив уникання & 0,47 & $-0,20$ & $-0,18$ & $-0,17$ & 0,08 & 0,57 & $-0,11$ & 0,09 \\
\hline лагання & 0,77 & $-0,12$ & 0,16 & 0,24 & 0,23 & 0,34 & $-0,06$ & 0,08 \\
\hline товаг & 0,11 & 0,71 & 0,00 & $-0,44$ & 0,12 & 0,21 & 0,02 & 0,24 \\
\hline ладності & 0,47 & $-0,29$ & $-0,54$ & 0,29 & 0,14 & 0,23 & 0,23 & 0,13 \\
\hline вольового & 0,28 & $\mathbf{0 , 7 0}$ & $0,45 \mid$ & $-0,22$ & 0,09 & 0,05 & $-0,14$ & $-0,01$ \\
\hline ни вла & 0,25 & 0,23 & 0,27 & -0.57 & 0,09 & $-0 ?$ & $-0,04$ & 0,38 \\
\hline ціативності & 0,16 & $-0,15$ & $-0,15$ & $-0,60$ & 0,32 & $-0,29$ & 0,45 & 0,14 \\
\hline $\begin{array}{l}\text { редженості } \\
\text { aтi }\end{array}$ & 0,47 & 0 , & 0,25 & $-0,10$ & 0,16 & 0,49 & $-0,06$ & 0,26 \\
\hline житті (СЖО) & $-0,75$ & $-0,19$ & $-0,13$ & 0,00 & $-0,02$ & 0,10 & $-0,02$ & 0,03 \\
\hline с життя (СЖ & $-0,88$ & $-0,04$ & $-0,05$ & 0,19 & 0,13 & 0,15 & $-0,11$ & 0,05 \\
\hline тативність житт & $-0,85$ & $-0,09$ & 0,16 & 0,14 & 0,17 & 0,13 & 0,05 & 0,03 \\
\hline $\begin{array}{l}\text { Локус-контролю Я } \\
\text { (СЖО) }\end{array}$ & $-0,82$ & $-0,15$ & 0,00 & 0,15 & $\mid-0,17$ & 0,21 & 0,19 & $-0,05$ \\
\hline Локус-контролю життя & $-0,80$ & 0,02 & 0,16 & 0,04 & $-0,08$ & 0,18 & 0,12 & 0,07 \\
\hline $\begin{array}{l}\text { Загальний рівень } \\
\text { смисложиттєвих } \\
\text { орієнтацій (СЖО) }\end{array}$ & $-0,93$ & $-0,11$ & 0,01 & 0,11 & 0,00 & 0,18 & 0,04 & 0,02 \\
\hline Ідеалізм & 0,07 & 0,27 & $-0,25$ & 0,27 & $-0,07$ & 0,24 & 0,22 & 0,41 \\
\hline Релятивізм & 0,36 & $-0,19$ & 0,09 & $-0,35$ & $-0,23$ & $-0,08$ & $-0,30$ & $-0,04$ \\
\hline
\end{tabular}


Отримані результати вказують на те, що за активної «ресурсності» перші 8 факторів пояснюють 76\% контенту. Головними показниками ресурсної актуалізації смислового конструкту є змагальний мотив, мотив самоповаги, мотив вольового зусилля, ресурс допомоги іншим і ресурс успіху, цінність стимуляції, відсутність цінності влади. Дані щодо не входження показника загального рівня смисложиттєвих орієнтацій і його компонентів до контенту ресурсної актуалізації смислового конструкту ми інтерпретуємо як недетермінованість нового смислового конструкту змістом попереднього. Співвідношення показників ідеалізму і peлятивізму дає змогу зробити висновки щодо формування етичної позиції ситуаціонізму.

За активної «мотиваційності» дані, включені до аналізу, структуровані за 8-ма факторами, що у сукупності пояснюють 100\% контенту (табл. 4). Варто зауважити, що $43 \%$ контенту входять до фактора 1 , що свідчить про значну структурованість і взаємозумовленість компонентів мотиваційної актуалізації смислового конструкту.

Таблиия 4

Результати аналізу головних компонентів психологічної реальності особистості за її мотиваційної зумовленості

\begin{tabular}{|c|c|c|c|c|c|c|c|c|}
\hline \multirow{2}{*}{ Шкали } & \multicolumn{8}{|c|}{ Об’єднання шкал у фактори } \\
\hline & 1 & 2 & 3 & 4 & 5 & 6 & 7 & 8 \\
\hline 1 & 2 & 3 & 4 & 5 & 6 & 7 & 8 & 9 \\
\hline Ресурс упевненості у собі & $-0,59$ & 0,20 & 0,17 & 0,59 & $-0,33$ & $-0,23$ & $-0,16$ & $-0,17$ \\
\hline Ресурс доброти до інших & $-0,89$ & $-0,01$ & $-0,38$ & $-0,10$ & 0,03 & $-0,09$ & $-0,14$ & 0,06 \\
\hline Ресурс допомоги іншим & $-0,76$ & $-0,45$ & 0,15 & 0,31 & $-0,09$ & $-0,04$ & $-0,23$ & 0,14 \\
\hline Ресурс успіху & $-0,74$ & 0,31 & 0,45 & $-0,00$ & 0,10 & $-0,32$ & $-0,15$ & 0,07 \\
\hline Ресурс любові & $-0,78$ & $-0,29$ & $-0,21$ & 0,05 & $-0,26$ & $-0,40$ & 0,08 & $-0,10$ \\
\hline Ресурс творчості & $-0,97$ & $-0,04$ & 0,14 & 0,04 & 0,13 & 0,03 & 0,07 & $-0,09$ \\
\hline Ресурс віри у добро & $-0,84$ & 0,17 & $-0,06$ & $-0,25$ & $-0,17$ & $-0,15$ & $-0,07$ & 0,33 \\
\hline $\begin{array}{l}\text { Ресурс прагнення } \\
\text { мудрості }\end{array}$ & $-0,78$ & 0,27 & $-0,15$ & $-0,46$ & 0,17 & $-0,06$ & $-0,12$ & 0,13 \\
\hline
\end{tabular}


Продовження табл. 4

\begin{tabular}{|c|c|c|c|c|c|c|c|c|}
\hline 1 & 2 & 3 & & & 6 & 7 & 8 & 9 \\
\hline Ресурс роботи над собою & $-0,47$ & 0,22 & $-0,17$ & $-0,70$ & $-0,23$ & $-0,06$ & 0,26 & $-0,27$ \\
\hline $\begin{array}{l}\text { Ресурс самореалізації у } \\
\text { професії }\end{array}$ & $-0,83$ & $-0,08$ & 0,06 & 0,07 & 0,42 & $-0,09$ & 0,28 & $-0,10$ \\
\hline Ресурс відповідальності & $-0,51$ & $-0,38$ & 0,06 & 0,40 & $-0,16$ & $-0,09$ & 0,61 & $-0,04$ \\
\hline Знання власних 1 & $-0,83$ & $-0,41$ & 0,10 & $-0,15$ & $-0,13$ & $-0,06$ & $-0,26$ & $-0,07$ \\
\hline $\begin{array}{l}\text { міння оновлюв } \\
\text { есурси }\end{array}$ & $-0,92$ & $-0,16$ & $-0,20$ & $-0,17$ & $-0,04$ & $-0,01$ & $-0,19$ & $-0,04$ \\
\hline $\begin{array}{l}\text { Уміння вміщувати } \\
\text { ресурси }\end{array}$ & $-0,73$ & $-0,36$ & $-0,22$ & $-0,25$ & 0,38 & 0,07 & $-0,21$ & 0,15 \\
\hline inoï & 0,00 & $-0,08$ & $-0,04$ & $-0,07$ & $-0,00$ & $-0,13$ & $-0,04$ & 0,00 \\
\hline Цінні & $-0,67$ & 0,34 & $-0,11$ & $-0,35$ & $-0,27$ & 0,34 & 0,29 & $-0,08$ \\
\hline Цінғ & $-0,28$ & 0,35 & 0,15 & 0,37 & $-0,24$ & 0,65 & $-0,20$ & $-0,29$ \\
\hline $\begin{array}{l}\text { Цінні } \\
\text { добро }\end{array}$ & 080 & 0,14 & 029 & 0,13 & -005 & 0,30 & 0,14 & $-0,13$ \\
\hline Цінн & $-0,31$ & $-0,21$ & $-0,59$ & $-0,25$ & 0,07 & 0,61 & $-0,12$ & 0,18 \\
\hline Цінність самостійності & $-0,58$ & 0,24 & 0,00 & 0,04 & 0,08 & $-0,06$ & $-0,49$ & $-0,58$ \\
\hline Цінність стимуляції & $-0,80$ & 0,26 & 0,15 & 0,28 & $-0,18$ & $-0,08$ & $-0,16$ & 0,32 \\
\hline Цінність гедонізму & $-0,85$ & 0,25 & $-0,27$ & 0,22 & 0,08 & 0,15 & 0,09 & $-0,19$ \\
\hline Цінність досягнення & $-0,57$ & 0,10 & 0,54 & 0,28 & $-0,29$ & 0,24 & 0,29 & 0,20 \\
\hline лади & 0,07 & 0,42 & 0,65 & 0,55 & $-0,19$ & 0,18 & $-0,05$ & 0,01 \\
\hline безпеки & $-0,39$ & $-0,28$ & 0,76 & $-0,20$ & 0,16 & 0,25 & $-0,06$ & $-0,17$ \\
\hline $\begin{array}{l}\text { осередженості } \\
\text { есі }\end{array}$ & 0,01 & $-0,87$ & $-0,19$ & 0,41 & $-0,00$ & 0,13 & $-0,06$ & $-0,01$ \\
\hline Пізнавальний мотив & 0,50 & $-0,41$ & $-0,62$ & 0,40 & $-0,12$ & $-0,01$ & $-0,02$ & $-0,09$ \\
\hline Мотив уникання & 0,73 & 0,64 & $-0,03$ & $-0,18$ & $-0,01$ & $-0,10$ & 0,05 & $-0,02$ \\
\hline Мотив змагання & $\mathbf{0 , 8 1}$ & 0,42 & $-0,36$ & 0,00 & $-0,08$ & $-0,12$ & 0,03 & $-0,07$ \\
\hline поповаг & $-0,88$ & $-0,29$ & $-0,31$ & 0,14 & $-0,09$ & $-0,03$ & $-0,04$ & $-0,02$ \\
\hline ладності & 0,34 & $-0,13$ & $-0,82$ & 0,33 & 0,11 & $-0,11$ & $-0,01$ & $-0,12$ \\
\hline вольового & $=0$ & 0,50 & 0,53 & $-0,41$ & 0,09 & $-0,01$ & 0,03 & 0,07 \\
\hline оцінки влас & $0, \%$ & , & 0,00 & 0,00 & $\mid-0,03$ & $-0,0$ & $-0,0$ & 0,01 \\
\hline Мотив ініціативності & $-0,14$ & $-0,87$ & 0,29 & 0,24 & 0,11 & 0,22 & $-0,05$ & 0,05 \\
\hline
\end{tabular}


Продовження табл. 4

\begin{tabular}{|l|c|c|c|c|c|c|c|c|}
\hline \multicolumn{1}{|c|}{1} & 2 & 3 & 4 & 5 & 6 & 7 & 8 & 9 \\
\hline $\begin{array}{l}\text { Мотив зосередженості } \\
\text { на результаті }\end{array}$ & $-0,67$ & 0,37 & $-0,56$ & $-0,02$ & $-0,18$ & $-0,21$ & 0,00 & $-0,07$ \\
\hline Цілі у житті (СЖО) & $-0,49$ & 0,38 & 0,00 & 0,13 & 0,75 & 0,06 & 0,09 & 0,03 \\
\hline Процес життя (СЖО) & $-0,19$ & 0,60 & $-0,59$ & 0,03 & $-0,16$ & 0,35 & $-0,06$ & 0,28 \\
\hline $\begin{array}{l}\text { Результативність життя } \\
\text { (СЖО) }\end{array}$ & 0,05 & 0,53 & $-0,43$ & 0,43 & 0,55 & 0,10 & $-0,14$ & 0,06 \\
\hline $\begin{array}{l}\text { Локус-контролю Я } \\
\text { (СЖО) }\end{array}$ & $-0,32$ & 0,55 & 0,03 & 0,52 & 0,41 & $-0,14$ & 0,25 & $-0,21$ \\
\hline $\begin{array}{l}\text { Локус-контролю життя } \\
\text { (СЖО) }\end{array}$ & $-0,24$ & 0,38 & 0,01 & $\mathbf{0 , 6 9}$ & $-0,42$ & $-0,15$ & $-0,12$ & 0,28 \\
\hline $\begin{array}{l}\text { Загальний рівень } \\
\text { смисложиттєвих } \\
\text { орієнтацій (СЖЖ) }\end{array}$ & $-0,35$ & $\mathbf{0 , 6 3}$ & $-0,21$ & 0,45 & 0,45 & 0,05 & 0,02 & 0,09 \\
\hline Ідеалізм & $-\mathbf{0 , 6 1}$ & 0,39 & $-0,13$ & $-0,17$ & $-0,54$ & 0,16 & 0,30 & $-0,02$ \\
\hline Релятивізм & 0,50 & $\mathbf{0 , 5 4}$ & 0,22 & $-0,18$ & $-0,35$ & 0,05 & $-0,47$ & $-0,11$ \\
\hline
\end{tabular}

Головними показниками мотиваційної актуалізації смислового конструкту є мотиви уникання і змагання, цілі традиції й універсалізму, загальний рівень смисложиттевих орієнтацій, локус-контролю Я, відсутність усіх психологічних ресурсів, а також інших мотиваційних цінностей, окрім уже вказаних. Вияв ресурсу впевненості у собі $є$ контроверсійним. Співвідношення показників ідеалізму і релятивізму дає змогу зробити висновки щодо формування етичної позиції суб’єктивізму. Те, що за мотиваційної актуалізації загальний рівень смисложиттєвих орієнтацій є показником смислового конструкту, ми інтерпретуємо як вибудову нового смислового конструкту на попередньому Означене є підтвердженням наявності установки.

Спільним у компонентах ресурсної та мотиваційної актуалізації смислового конструкту є наявність змагального мотиву. Водночас ресурсний контекст вияву цього мотиву дає нам змогу проінтерпретувати, що йдеться про боротьбу людини із самою собою, що виявлятиметься у саморозвитку. Мотиваційний контекст змагального мотиву вказує на прагнення людини зберегти рівень власного добробуту. 


\section{Висновки}

За результатами проведеного дослідження можна узагальнити, що актуалізація смислового конструкту реалізується у ресурсний і мотиваційний спосіб. За наявної ситуації дослідження смисловий конструкт актуалізовано ресурсами відповідальності, віри в добро, любові, допомоги іншим і неактивованістю мотивів уникання й змагання. Джерелом ресурсів є етична позиція суб'єктивізму, а джерелом мотивів - мотиваційні цінності досягнення і влади. Відтак, за наявної ситуації смислові перетворення хоча і зумовлені психологічною ресурсністю, водночас актуалізація смислового конструкту увиразнюється в індивідуалістичний спосіб. Водночас, за більшої довіри особи метанаративу, ресурсна актуалізація смислового конструкту стане первинною, й етична позиція особи зміниться на ситуаціоністичну.

Перетворення смислу, як демонструють результати дослідження, відбувається у три способи, зокрема, через мотиви пізнання, самоповаги, оцінки власного потенціалу, саме через останній мотив людиною усвідомлюється оперування власними психологічними ресурсами. Ресурс допомоги іншим є смислоперетворювальним, оскільки пов' язаний з обома джерелами смислового конструкту - саморозумінням і цінностями.

Головними показниками ресурсної актуалізації смислового конструкту є змагальний мотив, мотив самоповаги, мотив вольового зусилля, ресурс допомоги іншим і ресурс успіху, цінність стимуляції, відсутність цінності влади та недетермінованість нового смислового конструкту змістом попереднього, що свідчить про наявність смислових диспозицій. Головними показниками мотиваційної актуалізації смислового конструкту є мотиви уникання і змагання, цілі традиції й універсалізму, загальний рівень смисложиттєвих орієнтацій, локус-контролю Я. Загальний рівень смисложиттєвих орієнтацій є показником смислового конструкту, що означає наявність установки. 
Контроверсійність актуалізації смислового конструкту задана ресурсом допомоги іншим і мотиваційною цінністю прагнення влади й реалізується у змагальному мотиві. Ймовірно, за довіри до метанаративу, у висхідній етичній позиції особи переважатиме ідеалізм, що зумовить подальшу актуалізацію смислового конструкту в ресурсний спосіб. Відтак, відбуватиметься саморозвиток як самоздійснення. В іншому випадку - спосіб актуалізації смислового конструкту з високою ймовірністю буде мотиваційним, тобто особа скерується на шлях особистісного зростання, порівняно з іншими, і самозвеличення.

Результати дослідження обгрунтували, що ресурсний спосіб актуалізації смислового конструкту уможливлений здатністю особистості оперувати власними ресурсами, яку можна увиразнити через мотиви пізнання й оцінки власного потенціалу. Роль психологічних ресурсів в актуалізації смислового конструкту полягає у підтриманні зв'язку з метанаративом і, відтак, наближенні особистості у процесі смислових перетворень до автентичності.

\section{Література}

Батаршев А. В. Диагностика способности к общению. Санкт-Петербург : Питер, 2006. 176 с.

Брудный А. А. Психологическая герменевтика. Москва : Лабиринт, 2005. $336 \mathrm{c}$.

Знаков В. В. Самопонимание субъекта как когнитивная и экзистенциальная проблема. Психологический журнал. 2005. Т. 26. № 1. C. 18-28. URL : https://institut.smysl.ru/article/understand.php.

Знаков В. В. Тезаурусное и нарративное понимание события как проблема психологии человеческого бытия. Методология и история психологии. 2010. Вып. 3. Т. 5. С. 105-119. URL : https://mhpjournal.ru.

Извеков А. И. Рождение личности постмодерна в кризисе культуры. Исторические, философские, политические и юридические науки, культурология, искусствоведение. Вопросы теории и практики. 2012. № 9 (23): В 2-х ч. Ч. 1. С. $92-95$.

Капустин С. А. Вклад У. Джемса в представления о личности как психологической реальности. Национальный психологический журнал. 2017. № 1 (25). C. 62-69. 
Леонтьев Д. Психология смысла. Природа, строение и динамика смысловой реальности. 2-е изд. Москва : Смысл, 2003. URL : https:// books.google.com.ua.

Максименко С. Д. Поняття особистості в психології. Психологія $i$ особистість. 2016. № 1 (9). С. 11-17.

Петровский А. В., Ярошевский М. Г. Категориальный строй в психологии. 1998. URL : https://psylib.org.ua.

Розуміння та інтерпретація життєвого досвіду як чинник розвитку особистості: монографія / За ред. Н. В. Чепелєвої. Кіровоград : ІмексЛТД, 2013. $276 \mathrm{c.}$

Семків I. I. Адаптація методики Ш. Шварца «Портрет цінностей» українською мовою. Практична психологія та соціальна робота. 2013. № 1. С. 12-28.

Слотина Т. В. Психология личности. Санкт-Петербург : Питер, 2008. $304 \mathrm{c}$.

Штепа О. С. Опитувальник психологічної ресурсності особистості: результати розробки й апробації авторської методики. Проблели сучасної психологї: зб. наук. праць Кам'янець-Подільського національного університету імені Івана Огієнка, Інституту психології ілені Г. С. Костюка НАПН України / За наук. ред. С. Д. Максименка, Л. А. Онуфрієвої. Кам'янець-Подільський : Аксіома, 2018. Вип. 39. С. 380-399.

Штепа О. С. Ресурсна та мотиваційна актуалізація чуття самоефективності. Здоров'я у лультидисииплінарнолу дискурсі: Матеріали Міжнародної науково-практичної конференцї, м. Львів, 1113 квітня 2019 р. Львів : Український католицький університет, 2019. C. 91-94.

Bauer, J., Shwab, J., \& McAdams, D. (2011). Self-Actualization. Where Ego Development Finally Feel Good? The Humanisctic Psychologist, 39, 121-136. DOI 10/1080/08873267.2011.564978.

Forsyth, D. R., O’Boyle, E. H., \& McDaniel, M. A. (2008). East meets West: A meta-analytic investigation of cultural variations in idealism and relativism. Journal of Business Ethics, 83 (4), 813-833. DOI 10.1007/s10551-008-9667-6.

Krems, J., Kenrick, D., \& Neel, R. (2017). Individual Perceptions of Self-Actualization: What Functional Motives Are Linked to Fulfilling One's Full Potential? Personality and Social Psychology Bull., Sep.43(9), 1337-1352. DOI 10.1177/0146167217713191. Retrieved from https://www.ncbi.nlm.nih.gov.

\section{References}

Batarshev, A. V. (2006). Diagnostika sposobnosti $k$ obshcheniju [Diagnosis of ability to communicate]. Sankt-Peterburg : Piter [in Russian]. 
Brudnyj, A. A. (2005). Psihologicheskaja germenevtika [Psychological hermeneutics]. Moskva : Labirint [in Russian].

Znakov, V. V. (2005). Samoponimanie subjekta kak kognitivnaja i jekzistentsial'naja problema [Self-understanding of the subject as a cognitive and existential problem]. Psihologicheskij zhurnal-Psychological Journal, 1, Vol. 26, 18-28. Retrieved from https://institut. smysl.ru/article/understand.php [in Russian].

Znakov, V. V. (2010). Tezaurusnoe i narrativnoe ponimanie sobytija kak problema psihologii chelovecheskogo bytija [The thesaurus and narrative-oriented understanding of the event as a problem of human being]. Metodologija i istorija psihologii - Methodology and history of psychology, 3, Vol. 5, 105-119. Retrieved from https://mhp-journal. $\mathrm{ru}$ [in Russian].

Izvekov, A. I. (2012). Rozhdenie lichnosti postmoderna v krizise kul'tury [The birth of a postmodern personality in a crisis of culture]. Istoricheskie, filosofskie, politicheskie i juridicheskie nauki, kul'turologija, iskusstvovedenie - Historical, philosophical, political and law sciences, cultural studies, art history. Theory and practice, 9 (23), Vol. 1, 92-95 [in Russian].

Kapustin, S. A. (2017). Vklad U. Dzhejmsa v ptedstavlenija o lichnosti kak o psihologicheskoj real'nosti. [The contribution of William James to the concept of personality as a psychological reality]. Natsional'nyj psihologicheskij zhurnal - National Psychological Journal, 1 (25), 62-69 [in Russian].

Leont'ev, D. (2003). Psihologija smysla. Priroda, stroenie i dinamika smyslovoj real'nosti [Psychology of meaning. Nature, structure and dynamics of meaning reality]. Moskva : Smysl. Retrieved from https:// bookap.info [in Russian].

Maksymenko, S. D. (2016). Poniattia osobystosti v psykholohii [The concept of personality in psychology]. Psykholohiia $i$ osobystist - Psychology and personality, 1 (9), 11-17 [in Ukrainian].

Petrovskij, A. V., \& Jaroshevskij, M. G. (1998). Kategorial'nyj stroj $v$ psihologii. [Categorical structure of psychology]. Retrieved from https://psylib.org.ua [in Russian].

Chepelieva, N. V. (Ed.) (2013). Rozuminnia ta interpretatsiia zhyttievoho dosvidu yak chynnyk rozvytku osobystosti [Understanding and interpreting life experience as a factor in personality development]. Kirovohrad : Imeks-LTD [in Ukrainian].

Semkiv, I. I. (2013). Adaptatsiia metodyky Sh. Shvartsa "Portret tsinnostei» ukrainskoiu movoiu [Adaptation of Sh. Schwartz's «Portrait of Values» method in the Ukrainian language]. Praktychna psykholohiia ta sotsialna robota - Practical Psychology and Social Work, 1, 12-28 [in Ukrainian]. 
Slotina, T. V. (2008). Psihologija lichnosti [Psychology of Personality]. Sankt-Peterburg : Piter [in Russian].

Shtepa, O. S. (2018). Opytuvalnyk psykholohichnoi resursnosti osobystosti: rezultaty rozrobky i aprobatsii avtorskoi metodyky [The questionnaire of a personality's psychological resourcefulness: the result of development and approbation of the author's method]. Problemy suchasnoi psykholohii - Problems of Modern Psychology: Collection of research papers of Kamianets-Podilskyi National Ivan Ohiienko University, G. S. Kostiuk Institute of Psychology of the National Academy of Educational Sciences of Ukraine, 39, 380-399. KamianetsPodilskyi : Aksioma [in Ukrainian].

Shtepa, O. S. (2019). Resursna i motyvatsiina aktualizatsiia chuttia samoefektyvnosti [Resource and motivational actualization of the selfefficacy]. Zdorovia u multydystsyplinarnomu dyskursi-Health in a multidisciplinary discourse: Proceedings of the International Scientific and Practical Conference. (pp. 91-94). Lviv : Ukrainskyi katolytskyi universytet [in Ukrainian].

Bauer, J., Shwab, J., \& McAdams, D. (2011). Self-Actualization. Where Ego Development Finally Feel Good? The Humanisctic Psychologist, 39, 121-136. DOI 10/1080/08873267.2011.564978.

Forsyth, D. R., O’Boyle, E. H., \& McDaniel, M. A. (2008). East meets West: A meta-analytic investigation of cultural variations in idealism and relativism. Journal of Business Ethics, 83 (4), 813-833. DOI 10.1007/s10551-008-9667-6.

Krems, J., Kenrick, D., \& Neel, R. (2017). Individual Perceptions of Self-Actualization: What Functional Motives Are Linked to Fulfilling One's Full Potential? Personality and Social Psychology Bull., Sep.43(9), 1337-1352. DOI 10.1177/0146167217713191. Retrieved from https://www.ncbi.nlm.nih.gov.

\section{Штепа Олена. Значення психологічних ресурсів в актуалізації смисло- вих конструктів}

\section{АНОТАЦІЯ}

Сформульовано проблему емпіричної верифрікації двобічної актуалізації смислових конструктів. Емпіричне дослідження було реалізовано у моделі Нельсона, що полягає у визначенні сутності проблеми за наявних умов. Наявними умовами є соціально-культурний контекст життя, тому варто вказати, що термінальними межами дослідження $є$ жовтень 2018 - квітень 2019 рр. У емпіричному дослідженні взяли участь 214 осіб віком 20-65 років. За результатами проведеного дослідження можна узагальнити, що актуалізація смислового конструкту реалізу- 
ється у ресурсний і мотиваційний спосіб. За наявної ситуації дослідження смисловий конструкт актуалізовано ресурсами відповідальності, віри в добро, любові, допомоги іншим і неактивованістю мотивів уникання й змагання. Джерелом ресурсів є етична позиція суб'єктивізму, а джерелом мотивів - мотиваційні цінності досягнення і влади.

Головними показниками ресурсної актуалізації смислового конструкту є змагальний мотив, мотив самоповаги, мотив вольового зусилля, ресурс допомоги іншим і ресурс успіху, иінність стимуляції, відсутність цінності влади та недетермінованість нового смислового конструкту змістом попереднього, що свідчить про наявність смислових диспозицій. Головними показниками мотиваційної актуалізації смислового конструкту є мотиви уникання і змагання, цілі традиції й універсалізму, загальний рівень смисложиттєвих орієнтацій, локусконтролю Я. Загальний рівень смисложиттєвих орієнтацій є показником смислового конструкту, що означає наявність установки.

Контроверсійність актуалізації смислового конструкту задана ресурсом допомоги іншим і мотиваційною цінністю прагнення влади й реалізується у змагальному мотиві. Результати дослідження обгрунтували, що ресурсний спосіб актуалізації смислового конструкту уможливлений здатністю особистості оперувати власними психологічними ресурсами, яку можна увиразнити через мотиви пізнання й оцінки власного потенціалу. Роль психологічних ресурсів в актуалізації смислового конструкту полягає у підтриманні зв'язку з метанаративом і, відтак, наближенні особистості у процесі смислових перетворень до автентичності.

Ключові слова: психологічні ресурси, смисловий конструкт, актуалізація, мотиваційні цінності, мотиви, етична позиція, ресурсний і мотиваційний спосіб актуалізації.

\section{Штепа Елена. Значение психологических ресурсов в актуализации смысловых конструктов}

\section{АННОТАЦИЯ}

Сформулирована проблема эмпирической верификации двусторонней актуализации смысловых конструктов. Эмпирическое исследование было реализовано в модели Нельсона, позволяющей определить сущность проблемы в имеющихся условиях. Имеющимися условиями является социокультурный контекст жизни, поэтому следует указать, что исследование было проведено в октябре 2018 - апреле 2019 г2. В 
эмпирическом исследовании приняли участие 214 человек в возрасте 20-65 лет. На основании результатов исследования можно уточнить, что актуализация смыслового конструкта реализуется ресурсным и мотивационным способом. В имеющейся ситуации исследования смысловой конструкт актуализирован ресурсами ответственности, веры в добро, любви, помощи другим и неактивированностью мотивов избегания и соревновательности. Источником ресурсов является этическая позиция субъективизма, источником мотивов - мотивационные ценности достижения и власти.

Главными показателями ресурсной актуализации смыслового конструкта являются соревновательный мотив, мотив самоуважения, мотив волевого усилия, ресурс помощи другим и ресурс успеха, иенность стимулирования, отсутствие ценности власти и недетерминированность нового смыслового конструкта содержанием предыдущего, что свидетельствует о наличии смысловых диспозиций. Главными показателями мотивационной актуализации смыслового конструкта являются мотивы избегания и соревновательности, цели традиции и универсализма, общий уровень смысложизненных ориентаций, локус-контроля Я. Общий уровень смысложизненных ориентаций является показателем смыслового конструкта, что свидетельствует о наличии установки.

Контроверсийность актуализации смыслового конструкта задана ресурсом помощи другим и мотивационной ченностью стремления к власти и реализуется в соревновательном мотиве. Результаты исследования обосновали, что ресурсный способ актуализации смыслового конструкта возможен при способности личности оперировать собственными психологическими ресурсами, которую можно сделать более выразительной через мотивы познаний и оченки своего потенциала. Роль психологических ресурсов в актуализации смыслового конструкта состоит в поддержке связи с метанарративом и, собственно, приближении личности в процессе смысловых преобразований к аутентичности.

Ключевые слова: психологические ресурсы, смысловой конструкт, актуализация, мотивационные ценности, мотивы, этическая позиция, ресурсный и мотивационный способ актуализации. 